\title{
The effect of campylobacter lipopolysaccharide on fetal development in the mouse
}

\author{
A. M. O'SULLIVAN, C. J.DORÉ*, S. BOYLEt, C. R. COID and A.P. JOHNSON $\ddagger$ \\ Divisions of Comparative Medicine, "Medical Statistics, †Histopathology and $\ddagger$ Sexually Transmitted Diseases, \\ Clinical Research Centre, Watford Road, Harrow, Middlesex HA1 3 UJ
}

\begin{abstract}
Summary. Purified lipopolysaccharide (LPS) obtained from isolates of Campylobacter fetus ss. fetus and Campylobacter jejuni impaired fetal development when administered to mice on day 13 of pregnancy. Strikingly more fetal resorption was produced by $C$. jejuni LPS than by similar amounts of $C$. fetus ss. fetus LPS. Three of the four Campylobacter strains examined produced LPS that had no effect on maternal health, but LPS from one $C$. jejuni strain killed all of the mice to which it was administered.
\end{abstract}

\section{Introduction}

Organisms of the genus Campylobacter are associated with various infections in man and animals. The principal disease in man is enterocolitis, but cases of meningitis, abortion, arthritis and other systemic infections have also been reported. Infertility and abortion are the main features of the infection in ruminants (Skirrow, 1984).

Little is known about the mechanisms by which campylobacters cause disease. Earlier work in this laboratory showed that both live and heat-killed campylobacters impaired fetal development when injected into the 13-day pregnant mouse. It was suggested that endotoxin-like substances played a role in pathogenesis (O'Sullivan et al., 1988). The present report describes the effect of purified lipopolysaccharide - the endotoxin moiety (Smith, 1978) extracted from $C$. fetus ss. fetus (henceforth referred to as $C$. fetus) and $C$. jejuni on the development of the mouse embryo.

\section{Materials and methods}

\section{Campylobacter strains}

The two C. fetus strains were kindly supplied by $\operatorname{Dr} M$. B. Skirrow, Worcester Royal Infirmary and the two $C$. jejuni strains by Dr D. Seal, Northwick Park Hospital. These four human isolates were subcultured four times in this laboratory before use. Stock cultures were stored at $-70^{\circ} \mathrm{C}$. The $C$. fetus strains comprised no. 23907 , isolated from an ovarian abscess, and no. 613 , from a wound. The C. jejuni strains comprised no. 42734 , isolated from the watery faeces of a 77-year-old female patient, and no.

Received 9 Aug. 1987; accepted 6 Oct. 1987.
40630 , from the blood-stained faeces of a 26-year-old male patient. The campylobacters were cultured on horseblood agar plates (Gibco) and incubated at $37^{\circ} \mathrm{C}$ for $48 \mathrm{~h}$ in a micro-aerophilic environment produced by means of a "Campypack" (Oxoid). Before harvesting, each plate was checked for contaminants.

\section{Lipopolysaccharides (LPS)}

LPS was extracted from campylobacters by the method of Johnson and Perry (1976). Briefly, the bacteria were scraped from the surface of blood-agar plates with a loop and suspended in phenol $1 \%$ in pyrogen-free water. The bacterial suspensions were then placed in $50-\mathrm{ml}$ tubes (Falcon, Becton Dickinson) and centrifuged at $8000 \mathrm{rpm}$ at $4^{\circ} \mathrm{C}$ for $15 \mathrm{~min}$. The supernates were discarded and the pellets washed in ethanol $95 \%$ and lyophilised. The lyophilised cells were then suspended in $50 \mathrm{ml}$ of $50 \mathrm{mM}$ sodium phosphate buffer. After ultrasonic disintegration the cells were treated with ethylenediaminetetra-acetic acid (EDTA; BDH Chemicals Ltd), with lysozyme to digest cell-wall material, and with DNAase and RNAase to remove nucleic acids. Protein was then removed by the addition of phenol at $70^{\circ} \mathrm{C}$ and, after extensive dialysis, the LPS in the aqueous phase was collected by ultra-centrifugation.

The presence of protein contaminants $(<1.0 \mu \mathrm{g} / \mathrm{ml})$ in the LPS was estimated by the Bio-Rad Protein Assay (Bio-Rad Laboratories Ltd) and the presence of nucleic acids $(<0.1 \mu \mathrm{g} / \mathrm{ml})$ by electrophoresis on agarose gels followed by staining with ethidium bromide (Maniatis $e t$ al., 1982). DNA at a concentration of $0.1 \mu \mathrm{g} / \mathrm{ml}$, kindly supplied by Dr S. Rastan, was used as a standard. The Limulus Amoebocyte Assay (Sigma) was used for the detection of endotoxic activity. The LPS pellet was then lyophilised. For use it was suspended in pyrogen-free distilled water.

The LPS extracts of the four campylobacter strains were highly reactive (firm gel) in the Limulus clotting 
assay. The LPS, weighed before it was dissolved in pyrogen-free water, gave a Limulus activity equivalent of $3.04 \times 10^{\circ}$ Endotoxin Units (EU) $/ \mathrm{ml}$ and $3.04 \times 10^{-1}$ $\mathrm{EU} / \mathrm{ml}$ for $C$. fetus strains 23907 and 613 respectively and $3.04 \times 10^{3} \mathrm{EU} / \mathrm{ml}$ and $3.04 \times 10^{1} \mathrm{EU} / \mathrm{ml}$ of LPS for $C$. jejuni strains 42734 and 40630 respectively. Escherichia coli $\mathrm{LPS}$, at the same $\mathrm{w} / \mathrm{v}$, used for comparison, gave an activity equivalent of $3.04 \times 10^{4} \mathrm{EU} / \mathrm{ml}$.

\section{Mice}

Female mice of an outbred strain (TO/Crc) aged 10 weeks were obtained from the specific pathogen-free breeding unit at this Centre. The first day of pregnancy was taken to be that on which a vaginal plug was observed. Groups of mice were given LPS intravenously in $0.2-\mathrm{ml}$ doses containing $0.147,0.294,0.588$ and $1.176 \mathrm{mg}$. The control groups received $0.2 \mathrm{ml}$ of sterile pyrogen-free water. A further control group received $0.147 \mathrm{mg}$ of $E$. coli LPS (O127:B8; Difco Laboratories) in $0.2 \mathrm{ml}$ of pyrogen-free water.

\section{Statistical methods}

Probit analysis (Ross, 1980) was used to compare the dose-response relationship of the two $C$. fetus strains; a logarithmic scale was used for dose. The Mann-Whitney U and Fisher's exact tests (Armitage, 1971) were used for other comparisons as indicated in the text.

\section{Histology}

Fetal and placental tissues as well as sections from maternal liver, spleen, lung and kidneys were prepared for histological examination and stained with haemotoxylin and eosin.

\section{Results}

\section{Response of pregnant mice to campylobacter LPS}

As shown in the table, administration of LPS from both $C$. fetus and $C$. jejuni resulted in impaired fetal development.

To examine possible species and strain differences in the ability of LPS to cause fetal resorption, the dose (RD50) that would produce $50 \%$ resorptions was estimated by probit analysis. The RD50 for the LPS from $C$. fetus strain 23907 was $0.30 \mathrm{mg}$ / mouse $(95 \%$ confidence interval $0 \cdot 23-0 \cdot 40)$; for $C$. fetus strain 613 it was $0.45 \mathrm{mg} / \mathrm{mouse}(95 \%$ confidence interval $0 \cdot 32-0 \cdot 61$ ). There was no more than a suggestion of a difference in the dose-response relationship between curves of the two strains $(p=0.08)$.

At all doses investigated, $C$. jejuni LPS produced resorption of all of the mouse fetuses. The RD50 must therefore have been $<0.147 \mathrm{mg} /$ mouse, the lowest dose studied. Furthermore, LPS from $C$. jejuni strain 42734 killed all of five mice when given in a dose of $1.176 \mathrm{mg}$. No deaths occurred in any other groups $(p=0.02$; Fisher's exact test). The deaths occurred $24-48 \mathrm{~h}$ after administration of LPS; no diarrhoea was observed, but vaginal bleeding was evident.

These experiments demonstrated a significant difference in the ability of LPS from $C$. fetus and $C$.

Table. Effects of campylobacter LPS on the development of the 13-day mouse fetus

\begin{tabular}{|c|c|c|c|c|c|c|}
\hline \multirow[b]{2}{*}{$\begin{array}{l}\text { Campylobacter } \\
\text { strain }\end{array}$} & \multicolumn{4}{|c|}{$\begin{array}{l}\text { Mean percentage fetal resorption (range) in mice treated with LPS in a } \\
\text { dose ( } \mathrm{mg} / \text { mouse) of }\end{array}$} & \multicolumn{2}{|c|}{$\begin{array}{l}\text { Mean percentage fetal resorption } \\
\text { in mice treated with }\end{array}$} \\
\hline & $0 \cdot 147$ & 0.294 & 0.588 & $1 \cdot 176$ & $\begin{array}{l}\text { pyrogen-free } \\
\text { water }\end{array}$ & $\begin{array}{l}\text { E. coli } \mathrm{LPS} \\
0 \cdot 147 \mathrm{mg}\end{array}$ \\
\hline $\begin{array}{l}\text { C. fetus } \\
23907\end{array}$ & $\begin{array}{c}18 \\
(0-40) \\
n=4\end{array}$ & $\begin{array}{c}34 \\
(0-100) \\
n=4\end{array}$ & $\begin{array}{c}98 \\
(90-100) \\
n=4\end{array}$ & $\begin{array}{c}95 \\
(75-100) \\
n=5\end{array}$ & $\begin{array}{c}0 \\
(0-0) \\
n=5\end{array}$ & $\begin{array}{c}100 \\
(100-100) \\
n=5\end{array}$ \\
\hline $\begin{array}{l}\text { C. fetus } \\
613\end{array}$ & $\begin{array}{c}0 \\
(0-0) \\
n=3\end{array}$ & $\begin{array}{l}13 \\
(0-38) \\
n=3\end{array}$ & $\begin{array}{c}64 \\
(0-100) \\
n=4\end{array}$ & $\begin{array}{c}100 \\
(100-100) \\
n=4\end{array}$ & $\begin{array}{c}2 \\
(0-11) \\
n=6\end{array}$ & $\begin{array}{c}100 \\
(100-100) \\
n=6\end{array}$ \\
\hline $\begin{array}{r}\text { C. jejuni } \\
42734\end{array}$ & $\begin{array}{c}100 \\
(100-100) \\
n=4\end{array}$ & $\begin{array}{c}100 \\
(100-100) \\
n=5\end{array}$ & $\begin{array}{c}100 \\
(100-100) \\
n=5\end{array}$ & $\begin{array}{c}100 \\
(100-100) \\
n=5\end{array}$ & $\begin{array}{c}7 \\
(0-33) \\
n=5\end{array}$ & $\begin{array}{c}100 \\
(100-100) \\
n=4\end{array}$ \\
\hline $\begin{array}{r}\text { C. jejuni } \\
40630\end{array}$ & $\begin{array}{c}100 \\
(100-100) \\
n=5\end{array}$ & $\begin{array}{c}100 \\
(100-100) \\
n=4\end{array}$ & $\begin{array}{c}100 \\
(100-100) \\
n=5\end{array}$ & $\begin{array}{c}100 \\
(100-100) \\
n=5\end{array}$ & $\begin{array}{c}4 \\
(0-14) \\
n=4\end{array}$ & $\begin{array}{c}100 \\
(100-100) \\
n=5\end{array}$ \\
\hline
\end{tabular}

$\mathrm{n}=$ Number of mice per group. 
jejuni to impair fetal development $(\mathrm{p}=0.001$ by the Mann-Whitney $U$ test at LPS dose $0 \cdot 147 \mathrm{mg}$ ).

\section{Histological examination}

The pathological changes observed in the fetal and maternal tissues of animals inoculated with endotoxin from $E$. coli, C. fetus or $C$. jejuni were similar. Embryonic tissues were degenerate, cells lining the vascular spaces of the placenta were swollen, and there was focal necrosis (figure). Patchy fibrin deposition in vascular spaces and focal calcification were also evident in the placentas.


Figure. Transverse section of the fetal (F)-placental $(P)$ junctions from mice on day 18 of pregnancy; $\times 102 \cdot 5$. C. Normal fetalplacental junction (Top). T. Fetal-placental junction from a mouse treated on day 13 with $C$. jejuni LPS (Bottom). 
Maternal livers showed focal necrosis and inflammation. The spleens appeared congested and showed occasional macrophages containing haemosiderin. The lungs, which were also congested, showed focal haemorrhages. No pathological changes were seen in the kidneys.

\section{Discussion}

Recent studies (O'Sullivan et al., 1988) demonstrated that the inoculation of 13-day pregnant mice with live or heat-killed strains of Campylobacter led to impaired fetal development, the findings resembling those observed in mice treated with purified $E$. coli endotoxin (Coid, 1976). It was suggested, therefore, that endotoxin contributed, at least in part, to the pathogenesis of infection.

The present experiments demonstrate that LPS extracted from campylobacters also causes resorption of the 13-day mouse fetus and the pathological changes are indeed similar to those seen after inoculation with purified $E$. coli LPS or with live or heat-killed campylobacters. This observation strengthens the view that endotoxin is one of the active components responsible for impaired fetal development. A similar conclusion was reached by Osborne and Smibert (1964), who injected campylobacter organisms into pregnant heifers, and by Osborne (1965), who showed that the pathological changes were similar to those produced by $E$. coli endotoxin. The LPS of the Enterobacteriaceae has been well characterised (Lüderitz et al., 1982; Hitchcock and Brown, 1983) and studies by Perez-

\section{REFERENCES}

Armitage P 1971 Statistical methods in medical research. Blackwell Scientific, Oxford.

Coid C R 1976 Bacterial endotoxin and impaired fetal development. Experientia 32:735-736.

Fumarola D, Miragliotta G, Jirillo E 1982 Endotoxin-like activity associated with heat-killed organisms of the genus Campylobacter. In: Newell D G (ed) Campylobacter: epidemiology, pathogenesis and biochemistry. MTP Press, Lancaster, pp 185-187.

Hitchcock P J, Brown T M 1983 Morphological heterogeneity among Salmonella lipopolysaccharide chemotypes in silverstained polyacrylamide gels. Journal of Bacteriology 154:269-277.

Johnson K G, Perry M B 1976 Improved techniques for the preparation of bacterial lipopolysaccharides. Canadian Journal of Microbiology 22: 29-34.

Lüderitz $O$, Freudenberg $M A$, Galanos C, Lehmann V, Rietschel E T, Shaw D H 1982 Lipopolysaccharides of gram-negative bacteria. Current Topics in Membranes and Transport 17:79-151.

Maniatis T, Fritsch E F, Sambrook J 1982 Molecular cloning.
Perez et al. (1986) and Naess and Hofstad (1984) have shown that the LPS of Campylobacter spp. is similar. Moreover, electronmicroscopic studies in this laboratory on campylobacter LPS have shown the same morphological structure as in LPS isolated from other gram-negative bacteria (Shands, 1971).

The response of pregnant mice to the campylobacter LPS varied both between species and between strains. It was interesting to note that there was a correlation between the results obtained in vivo and in vitro; the extract that gave the highest activity in the Limulus test was the most toxic in mice in that it not only caused resorption of all embryos but was lethal for the pregnant mice in higher doses. Campylobacter LPS was much less potent than that of $E$. coli. Fumarola et al. (1982) observed that $E$. coli endotoxin was more potent than $C$. jejuni or $C$. coli heat-killed suspensions, in the dermal Shwartzman reaction as well as in the Limulus assay. Studies by Perez-Perez and Blaser (1985) showed that $C$. jejuni strains possessed a rough type of LPS with few or no polysaccharide side chains, whereas $C$. fetus strains possessed a smooth type of LPS. These differences suggest that the toxicity of the LPS is related to its structure.

It is concluded that LPS is, at least in part, responsible for bringing about the pathological changes caused by organisms of the genus Campylobacter.

We thank Dr S. Rastan and Mrs H. Davies for helpful advice and comments during the preparation of this paper and Miss $J$. MacKenzie for the photography.

A laboratory manual. Cold Spring Harbor Laboratory, Cold Spring Harbor, NY.

Naess V, Hofstad T 1984 Chemical composition and biological activity of lipopolysaccharides prepared from type strains of Campylobacter jejuni and Campylobacter coli. Acta Pathologica Microbiologica et Immunologica Scandinavica, Section B 92:217-222.

Osborne J C 1965 Pathological responses in animals after Vibrio fetus toxin shock. American Journal of Veterinary Research 26: 1056-1067.

Osborne J C, Smibert R M 1964 Vibrio fetus toxin. 1. Hypersensitivity and abortifacient action. The Cornell Veterinarian 54:561-572.

O’Sullivan A M, Doré C, Coid C R 1988 Campylobacters and impaired fetal development in mice. Journal of Medical Microbiology 25:7-12.

Perez-Perez G I, Blaser M J 1985 Lipopolysaccharide characteristics of pathogenic campylobacters. Infection and Immunity 47:353-359.

Perez-Perez G 1, Hopkins, J A, Blaser M J 1986 Lipopolysaccharide structures in Enterobacteriaceae, Pseudomonas aeruginosa and Vibrio cholerae are immunologically related to Campylobacter spp. Infection and Immunity 51 :204-208. 
Ross G J S 1980 MLP-Maximum Likelihood Program. Rothamsted Experimental Station, Harpenden.

Shands J W 1971 The physical structure of bacterial lipopolysaccharides. In: Weinbaum G et al. (eds) vol. 6, Bacterial endotoxins. Microbial toxins, Academic Press, London, pp 127-144.

Skirrow M B 1984 Campylobacter infections of man. In : Easmon
C S F, Jeljaszewicz J (eds) Medical microbiology, vol. 4. Academic Press, London, pp 105-141.

Smith H 1978 The determinants of microbial pathogenicity. In: Norris J R, Richmond M H (eds) Essays in microbiology, chapter 13. John Wiley and Sons, Chichester, pp 13/1-13/ 32. 
